\title{
A demanding form: William Faulkner and the short story
}

\section{Eoin 0' Callaghan}

School of English, UCC

\begin{abstract}
I'm a failed poet. Maybe every novelist wants to write poetry first, finds he can't, and then tries the short story, which is the most demanding form after poetry. And, failing at that, only then does he take up novel writing.
\end{abstract}

William Faulkner to Jean Stein, 1956

\section{Introduction}

Few authors have had such an impact on the American literary canon as the Southern novelist William Faulkner. His fiction of four decades not only constitutes an extensive exploration of Southern people and their environment, but represents a study of universal human tragedies and moral struggles. The zenith of Faulkner's career was his receipt, in 1949, of the Nobel Prize for Literature. Faulkner outlined, in his acceptance address, his belief in the endurance of man and the potential of writing to help him prevail. In particular, he advocated a return to what he perceived to be the principal theme of writing: the problems of the human heart in conflict with itself. His receipt of the award was naturally a turning point in his lengthy career. Its prestige and promise of financial security helped to ameliorate his financial struggles and to cement his position as an American master of letters.

Some details of Faulkner's early artistic forays are worth mentioning here. Following a short-lived career as a poet in the 1920s, Faulkner began a fortuitous sojourn in New Orleans with the established author, Sherwood Anderson. Anderson encouraged Faulkner to draw upon his own experiences in small-town Mississippi and to incorporate his Southern background into his fiction, which Faulkner did in his creation of Yoknapatawpha County. Yoknapatawpha is a fictional locality partially modelled on Faulkner's home county of Lafayette, but it is simultaneously an imaginative playground in which Faulkner is able to dexterously direct characters from novel to novel. Yoknapatawpha is the setting for many of Faulkner's most acclaimed novels and short stories of the 1930s. Faulkner was, however, and by all accounts, contrary in his opinions of Yoknapatawpha, holding an ambivalent view of its relative importance in his work.

Faulkner's opacity on this particular subject is not unusual. Faulkner sometimes claimed that his Southern characters acted autonomously and that he would merely walk along behind them to note down what happened. On other occasions, he fully embraced his 
self-proclaimed role as sole owner and proprietor of Yoknapatawpha County, free to summon or instruct any character as he required. Scholars have therefore been forced to negotiate a tangled web of remarks and interpretations in order to deduce his true feelings on a given subject. Faulkner's attitude to his short stories has been particularly difficult to circumscribe, and a definitive theory of Faulkner's short fiction has thus far eluded scholars. In the course of this essay, and in my wider research, I aim to determine Faulkner's working philosophy of the short story and to establish whether his recommendations for the short story genre are in fact reflected in his body of short fiction. Faulkner's short stories have been ill-treated in the field of Faulkner criticism, with only a handful of critics completing full-length studies of the short fiction. Short story theory in general has only recently begun to generate a large amount of scholarship, and it has deemed Faulkner to be of little consequence in the genre. My research, therefore, also seeks to challenge and change the relative neglect of the short story work in Faulkner Studies.

\section{His canon}

Despite his habitual insistence that he had failed at writing in the short story form, taking recourse, instead, in the novel, Faulkner in fact managed to achieve varying degrees of success in both genres throughout his career. Like many of his American coevals, including Ernest Hemingway and F. Scott Fitzgerald, Faulkner spent a considerable portion of his career writing short stories, producing at least 100 works of short fiction. Roughly 70 of these stories were published in his lifetime and several others, which he had been unable to sell to literary magazines or include in collections, were published posthumously by his chief biographer in 1979. Many of his most impressive stories were also written during his most productive novel-writing period; indeed, these stories contain, and perhaps enable, an even more dazzling panoply of genres and settings than his boldly experimental novels of the 1930s. Such a feat, however, has not been widely recognised or accepted by scholars and critics.

Faulkner's career as a short story writer can broadly be categorised according to three phases. During his apprenticeship to Sherwood Anderson and alongside the publication of his early novels in the late 1920s, Faulkner drafted several stories which he recuperated for publication late in his career. Many of Faulkner's unpublished stories also date from this period. Faulkner's second phase, bookended approximately by the years 1930 and 1938, saw the author write and publish the majority of his short fiction. His most famous and most anthologised stories also date from this phase. His final phase begins in 1938 and extends, effectively, until his death in 1962. During this phase, Faulkner at last acquired the financial independence and celebrity status which reduced his reliance on writing stories for literary magazines. He did, however, incorporate several older stories into new novels and short story collections. Faulkner's short story career, as a whole, can be described as circular in form: in his later years, Faulkner returned to many of the episodes, characters and ideas with which he had begun his fiction. 


\section{His comments}

Faulkner himself reserved a high degree of praise for the short story in his intermittent musings on literary form. He apparently considered the short story to be a challenging, precise art form that required as much skill and economy of language as poetry. He suggested, on more than one occasion, that the short story demands an "absolute exactitude" while the novel, by contrast, permits the author to be "slovenly and careless." He maintained this admiration for the short story form long after he had ceased to write extensively in the genre, judging by his letters and lectures in the latter stages of his career. Writing to Joan Williams, a would-be student and mistress of Faulkner's in the 1950s, Faulkner declared that the short story was "a crystallised instant" and that, next to poetry, it was "the hardest art form." Despite his more gruelling experiences selling stories in the 1930s, then, which will be addressed in detail below, Faulkner's opinion of the short story remained essentially positive.

It should be remembered that, in spite of his respect for the short story genre, Faulkner considered it to be beyond his powers as a writer. In fact, Faulkner, who was known for his self-deprecating manner, seems particularly critical and querulous with regards to his skills as a short story writer. In 1928, he confessed his belief that he had "no talent" for short stories, and that he persevered in submitting magazines to literary magazines with "unflagging optimism"-if little confidence. He also admitted in 1948 that he had never written a short story that he liked. Perhaps the negative reception which the short stories have received has been partly fuelled by Faulkner's own reservations about the short story work. Such misgivings on Faulkner's part only increased in frequency during the 1930s.

\section{His career}

Largely consistent throughout Faulkner's correspondence with his agents and editors in the 1930s is his belief that short stories, much like his purgatorial years writing screenplays in Hollywood, were his best means of generating income. In the 1930s, Faulkner had not yet achieved widespread critical success, with the majority of his books then out of print, but at least a degree of commercial success could be secured by publishing stories in literary magazines-even if Faulkner disliked the idea of supposedly prostituting himself. In 1932, Faulkner compared the process to "go[ing] whoring," indicating his increasingly desperate attempts to attract literary magazines by writing popular pieces that would sell quickly. In 1939, Faulkner wrote to Random House describing his struggles to pay his bills by writing short stories, and complaining that he would have to "hammer out another one."

Despite the fact that Faulkner often remarked upon this throwaway quality of his short story work and his ability to churn out stories at will, in actuality, it was not possible for Faulkner to compose stories at such a pace-due not only to the standards and stipulations of contemporary magazines, but also due to his own fastidiousness. Such perfectionism 
meant that many of Faulkner's short stories, and particularly those which were later reworked for incorporation into novels and short story collections, underwent significant revision prior to their appearance in literary publications and in book form. Faulkner obviously could not, without a certain modicum of inspiration, produce a short story on demand, even joking on one occasion that he would try to "get hold of one of the magazines and take a story that they will buy and change locale and names, etc." He even recognised that his need for money hindered his writing ability. He lamented in 1939 that his financial struggles had forced him to write "mechanical stories in which [he] had no faith."

One reason for the neglect of Faulkner's short stories is the argument that Faulkner's motivation for writing his stories was financial and not aesthetic-an opinion which would appear to be supported by Faulkner's cavalier attitude towards his magazine publications. Faulkner, too, was not above manipulating his work if he thought that alterations would help the story to secure a higher price in a magazine. This is despite his continued insistence that the short story was a carefully crafted form. However, it should be remembered that Faulkner was not alone among his contemporaries in publishing short stories to financial novels, F. Scott Fitzgerald being the best-known example. Furthermore, even if Faulkner did consider the short story to be his best means of generating money, such a feat does not negate his artistic achievements in the form and his success in developing a diverse range of stories. His substantial revisions to stories like "Lizards in Jamshyd's Courtyard," of which there are at least a dozen different manuscript and typescript versions, suggests his dedication to perfecting his material. In the majority of cases, these changes were not precipitated by the recommendations of magazine editors.

\section{His contributions}

The defining aspect of the short story is, of course, its brevity, and a reading at one-sitting criterion has been embraced, for the most part, since the inception of the short story and of short story theory in the writing of Edgar Allan Poe. Faulkner theorised that the best short stories were those of three thousand words or less and did not categorise much of his own work as short stories for this reason. During his time lecturing at the University of Virginia, Faulkner emphasised that reducing a story to three thousand words was a talent he did not possess. Expert craftsmen like Chekhov could tell a story in two thousand words, but lesser craftsmen, such as Faulkner himself, would require eighty thousand words. Many of Faulkner's most famous stories fail to follow this rule of thumb and are sometimes judged as novellas or short novels. His long stories are symptomatic of his distinctively inclusive writing style, often using multiple adjectives where only one is required.

But throughout his career, Faulkner consistently displays his flexibility with the form and length of the short story. For example, Faulkner was able to reduce an unfinished novel manuscript, known as Father Abraham and totalling roughly fifteen thousand words, to a 
lean eight thousand for its publication as the story "Spotted Horses." He was then able to extend and develop this story again for its inclusion in a late, three-volume work known as the Snopes Trilogy.

I propose that Faulkner's primary contribution to the development of the short story as a genre lies here-in his perceptive understanding of the relationship between short and novel forms. Short stories such as "Spotted Horses" are independent, autonomous units which can be enjoyed and understood by themselves. However, Faulkner realised that his short stories could gain new significance when incorporated into longer pieces of work. For the Snopes Trilogy, Faulkner combined a number of short stories which he had written and sold throughout the twenties and thirties. These stories, once integrated into the fabric of the Snopes novels, become episodes which lend thematic and structural unity to the trilogy. Faulkner may even have felt that to rework these stories would be to salvage material that he had written for financial reasons and to manipulate them for artistic purposes.

\section{Conclusion}

While Faulkner was ostensibly an accomplished short story writer and held a great admiration for the form, the novel undoubtedly remained his preferred form-his reputation is, after all, primarily based on his experimental novels. It is even likely that Faulkner enjoyed reading novels rather than short stories, and when questioned on multiple occasions about his favourite writers, he rarely mentioned short story authors. I argue, however, that Faulkner remained optimistic about the short story throughout his career, ranking it second only to poetry. Any disregard which Faulkner appears to demonstrate for the short story can be explained by the fact that his experience of writing short stories was often coloured by financial struggle. I suggest that the care with which Faulkner revised his stories - and particularly the collection or novels into which they were woven-is testament to his almost boundless capacity and propensity for rewriting and adapting his short fiction. Faulkner's key contribution to the development of a short story as a form lies his keen understanding of its relationship to the novel, or of the potential relationship short stories might bear to each other in the context of a longer work.

I wish to acknowledge the help and support of my supervisor, Professor Lee Jenkins. I would also like to thank the Irish Research Council, the UCC Strategic Research Fund and the School of CACSSS for providing funding during my research. 